\title{
Bekasi City Government Policy In Financing Stunting In Children
}

\author{
Rifa'at Hanifa Muslimah, Handar Subhandi Bakhtiar
}

Faculty of Law, Universitas Pembangunan Nasional Veteran Jakarta , Jakarta, Indonesia rifaathanifa.rh@gmail.com, handar_subhandi@yahoo.com

Article Information

Accepted : 05 Nov 2021

Submitted : 08 Nov 2021

Online Publish : 20 Nov

2021

\begin{abstract}
Currently, nutritional problems in Indonesia are still in the spotlight, one of which is the problem of stunting in toddlers. The government shows its commitment to tackling stunting by making regulations regarding the acceleration of stunting reduction as stated in Presidential Regulation No. 72 of 2021. The health financing system is an effort to fund the health sector to support the implementation of health with the aim of achieving the highest health status. This study aims to provide an overview of the Bekasi City government's policy in financing stunting prevention in Bekasi City. The research method used is normative juridical, with a statutory approach. The policies issued by the Bekasi City Government regarding the Prevention and Control of Stunting are contained in the Bekasi Mayor's Instruction No: 440/1914/Bappeda and the establishment of the Task Force for the Acceleration of Stunting Prevention and Control is contained in Decree Number: 440/Kep.277-Bappelitbangda/V/ 2020. The results of this study show that the participation of the Bekasi City government has been very good from issuing policies related to stunting reduction efforts, forming and implementing 8 integration actions by involving multi-sectoral roles in government which is an effort to prevent stunting. The financing used in the stunting prevention process is funded by the Bekasi City Government from the APBD (Anggaran Pendapatan dan Belanja Daerah) and or other funds that can be utilized by the relevant government sector to be in charge of 8 integration actions.
\end{abstract}

Keywords: Policy; Financing; Prevention of Stunting; 


\section{Introduction}

Stunting is one of the nutritional problems that occur in children caused by chronic malnutrition and repeated infections that cause growth and development disorders in children, it is characterized by the length or height of the child being below standards set by the Ministry of Health (Haskas, 2020) (Article 1 of Presidential Regulation Number 72 of 2021). The integration of the Study on the Nutritional Status of Indonesian Toddlers (SSGBI) and the Study on the Nutritional Status of Indonesian Toddlers (Susenas) showed that the stunting prevalence rate in 2019 was 6,538,564 children (27.7\%), where the areas with the lowest prevalence of stunting included Bali, Riau Islands, DKI Jakarta, and Bangka Belitung. There are still 30 provinces where the prevalence of stunting is above the WHO tolerance, which is $20 \%$. The Global Nutrition Report in 2016 noted that the prevalence of stunting in Indonesia was ranked 108 out of 132 countries. The prevalence of stunting in Indonesia occupies the second-highest position in Southeast Asia, of which Cambodia is in the first position. The target in accordance with the RPJMN (Rencana Pembangunan Jangka Menengah Nasional) 2020-2024 is to reduce the prevalence of stunting in children under the age of 2 years to 14\% (Directorate General of Regional Development, Ministry of Home Affairs, 2021).

Figure 1

National Starting Prevalence Data in 2019 (Integration of SSGBI and SUSENAS)

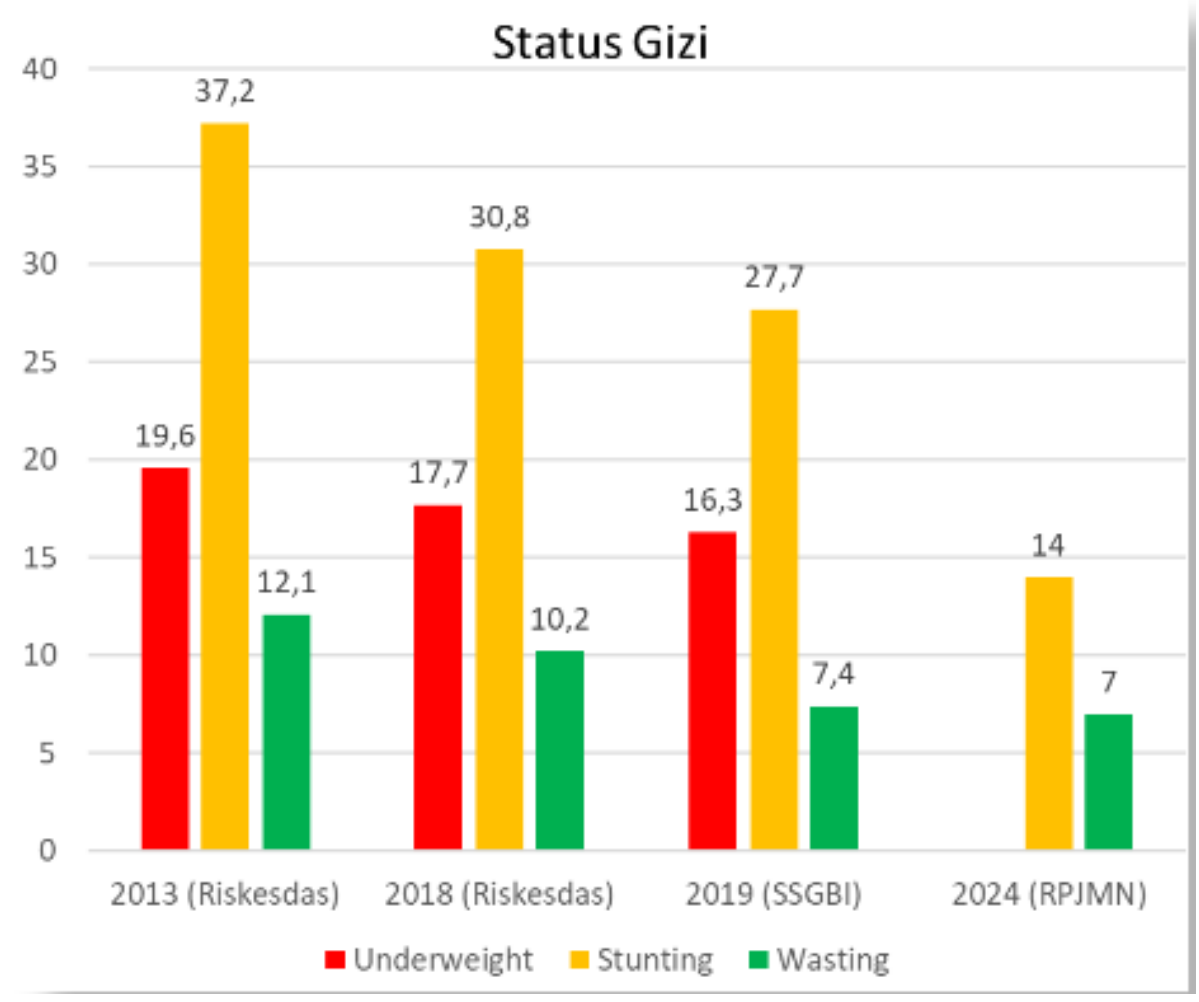

Technically in the implementation of reduction, it is stunting called 8 namely: 1. Identifying the distribution of cases of stunting, the state of availability of reduction 
programs stunting, and reduction management practices stunting, responsible for BAPPEDA. 2.

Planning further steps in city activities in realizing the recommendations of the results of the analysis of stunting conditions in the City of Bekasi, in charge of BAPPEDA. 3. Ensure the integrated implementation of interventions stunting between Regional Apparatus Organizations with non-government and community, SEKDA in charge. 4. Establish a regulation that explains the role and authority of the city government in planning and allocating a budget from the APBD for stunting prevention, the person in charge of the Community Empowerment Agency. 5. Forming a Human Development Cadre (KPM) who will participate in assisting the stunting locus area in facilitating integrated implementation, the person in charge of the Community Empowerment Agency. 6. From the village level to the city level, make efforts to manage accurate data to support the implementation of integration actions, BAPPEDA in charge. 7. At the primary health services to cross-sectoral villages and sub-districts, make efforts to obtain the prevalence rate stunting latest, the Person in Charge of the Health Office. 8. Conduct an evaluation by the city government regarding the performance of programs in each sector responsible for reducing stunting in the past year, in charge of SEKDA \& BAPPEDA (Directorate General of Regional Development, Ministry of Home Affairs, 2021).

\section{Research method}

Research is normative juridical research, with a statutory approach by examining a problem seen from the legal aspect and examining the applicable laws and regulations.

\section{Results and Discussion}

\section{A. Policy Analysis and Implementation}

In Badung Regency, the funding source for prevention stunting comes from the government with the allocation of central government funds $(70.16 \%)$, the Badung Regency Government (21.16\%), and the Bali Provincial Government (8.69\%). In prevention, $40 \%$ of these funds are prioritized for the lowest population (poor). Stunting in Indonesia $40 \%$ is influenced by the level of social and economic welfare, but it is possible that stunting is also experienced by non-poor families. In poor families, it is optimized through a family health education program on nutrition fulfillment by exclusive breastfeeding for the first 6 months in the hope of being one way to prevent stunting (Sugianto, 2020)

As for in Kubuaddan Village, Based on the problems of the policy on the allocation of village funds specifically for stunting prevention based on the implementation of PERMEN PDTT No. 16 of 2018 concerning the priority of using village funds in efforts to prevent stunting in Kubuaddan Village, from 30 respondents, 25 respondents $(83.3 \%)$ thought that the process of preparing a stunting 
prevention plan in Kubuaddan village was very good, and 5 respondents (17.7\%) thought it was good (Prihatini \& Subanda, 2020)

The Bekasi City Government shows its seriousness and commitment in prevention stunting by issuing a regulation on the Acceleration of Stunting Reduction as set out in Presidential Regulation Number 72 of 2021, which clearly states the objectives of the National Strategy for the Acceleration of reduction, Stunting namely: a. Reducing the prevalence of Stunting. b. Improving the quality of preparation for family life. c. Ensuring the fulfillment of nutritional intake. d. Improving parenting e. Improving access and quality of health services and $\mathrm{f}$. Improve access to drinking water and sanitation (Article 2 of Presidential Regulation Number 72 of 2021).

Based on the Bekasi Mayor's Instruction Number: 440/1914/Bappeda prevention and Control Stunting in Bekasi City, he instructs several government sectors to participate in prevention stunting and is also responsible for each of the integrated stunting actions, including the Development Planning Agency. Former City Area, Bekasi City Health Service, Bekasi City Disperkimtan, Bekasi City Education Office, Bekasi City Food Security Service, Bekasi City Women Empowerment and Child Protection Service (DP3A), Bekasi City Social Service, and Population Control and Family Planning Service

In the context of reducing stunting, the urban sector will participate in the following: a. Establish the authority of the ward in supporting the integration of stunting reduction interventions. b. Increase the allocation of the use of the APBD / Kelurahan Allocation for activities that can support stunting reduction. c. Implement interventions for integrated stunting reduction at the ward level by involving human development cadres (KPM). d. Increase the quantity and quality of the provision of stunting reduction services. e. Increase community participation to take advantage of stunting reduction services. At point $\mathrm{C}$ (Implementing interventions for integrated stunting reduction at the ward level by involving human development cadres) the expected output is ward coverage that has human development cadres and ward coverage with the certainty of operational cost support .

Community Health Center in carrying out activities in the community participates in healthcare center activities, healthcare center cares are involved by the health center in healthcare center activities for weighing, measuring height, providing additional food for malnourished toddlers and pregnant women with anemia or Chronic Energy Deficiency to health education. Because the frequency of healthcare center activities is quite complex, healthcare center plays a very important role in preventing and overcoming stunting (Dapamudang, Wulandari, \& Lesmana, 2021).

In a study conducted by (Norsanti, 2021) in Batumandi District, Balangan Regency, the factors that have an impact on the effectiveness of accelerating reduction stunting consist of good cooperation between nutrition officers from Batumandi Health Center, village midwives, Posyandu cadres, and PMT cadres as 


\section{Bekasi City Government Policy In Financing Stunting In Children}

supporting factor reduction acceleration program stunting. The obstacles are the lack of funding in the area, the level of parental education, the family's economic status, and the lack of socialization from certain sectors to the community about child care patterns (Norsanti, 2021)

In the allocation of funds for prevention or control of stunting in Padang Pariaman Regency in the research of (Syafrina, Masrul, \& Firdawati, 2019) that the budget for nutrition programs including the budget is stunting still insufficient, so activities have not run optimally. So that the efforts made by the government to tackle stunting through sanitation activities have not run optimally (Syafrina et al., 2019). The Bekasi City Government in the Bekasi Mayor Decree Number: 440/Kep.277-Bappelitbangda/V/2020 concerning the Task Force for the Acceleration of Prevention and Control of acceleration of Prevention and Control of StuntingStunting in the City of Bekasi in the decision letter explained that on May 4, 2021, formed a Task Force (Satgas) for thein Bekasi City. Prevention of Stunting in Bekasi City. In the fourth stipulation, it is stated that "All costs required in the implementation of this decision shall be borne by the Bekasi City Regional Revenue and Expenditure Budget."

The following is a recap of the use of the Bekasi City Regional Revenue and Expenditure Budget 2020 which is allocated for specific and sensitive nutrition interventions:

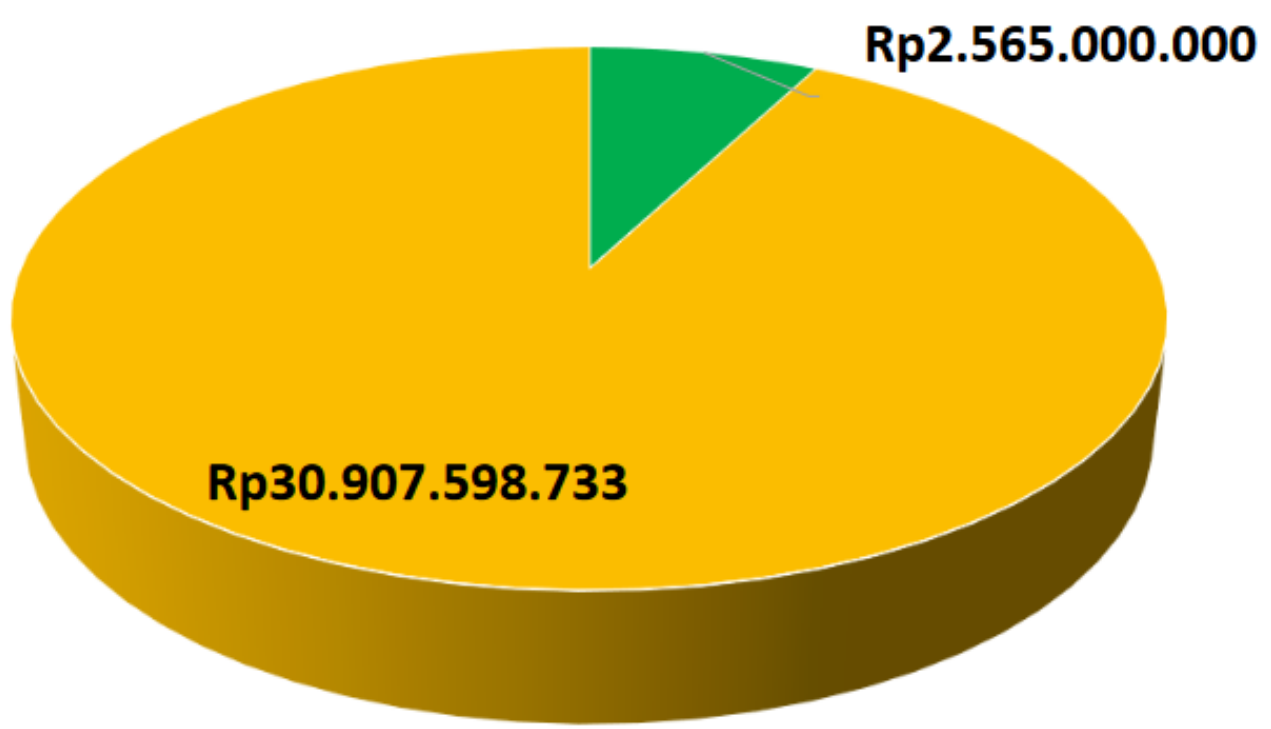

\section{- Spesifik $\quad$ Sensitif}

Source: Kemendagri Bangda Action Web (2020)

Home In an effort to reduce stunting, the Bekasi City Government carried out two ways of intervention, namely (1) specific nutrition interventions, to address the direct 
causes of stunting. The direct causes include: Improvement of nutritional intake, prevention and control of infection, improvement of maternal nutritional status, control of infectious diseases, and improvement of environmental health/sanitation. (2) To overcome the indirect causes of stunting with sensitive nutrition interventions. Sensitive nutrition interventions include: Increasing the availability of clean water and proper sanitation facilities, increasing the reach and quality of nutrition and health services, increasing awareness, commitment and practice of fulfilling maternal and child nutrition and increasing community needs in the consumption of nutritious food. Families and communities are the main targets of sensitive nutrition interventions, activities carried out through various cross-program and cross-sectoral collaborations with the same goal of improving the nutritional status of the community or individual (Ministry of National Planning and Development/National Planning and Development Agency, 2018).

The allocation of these funds is in line with research conducted by (Rosha, Sari, SP, Amaliah, \& Utami, 2016), that overcoming the problem of malnutrition is part of the concept developed by UNICEF, in the concept stating that nutritional problems are caused by direct causes and indirect causes which are also the root of the problem. problem. Efforts to overcome the problem of malnutrition require cross-sector collaboration in government and non-government through specific nutrition interventions and sensitive nutrition interventions because to overcome stunting specific interventions contribute $30 \%$ and $70 \%$ of sensitive nutrition interventions (Rosha et al., 2016).

Based on research conducted by (Indrastuty \& Pujiyanto, 2019) maternal employment status, housing, sanitation and economic status has a significant relationship with the occurrence of stunting as for other things that can deal with the problem of stunting in Indonesia is the intervention and the role as well as the right government and cross-sectoral participation (Indrastuty \& Pujiyanto, 2019). This study describes the indirect causes of stunting as factors that influence the prevalence of stunting in Indonesia so that the budget must also be allocated for the intervention of these indirect causes.

\section{Conclusion}

The government's role in shaping prevention financing policies stunting has been very good. The government also includes cross-sectoral collaboration to tackle stunting in Bekasi City. The financing used in the prevention process responsible for the stunting comes from the Regional Revenue and Expenditure Budget (APBD) as for other funds that can be used and utilized by the relevant sectors that are integration actions. 


\section{REFERENCE}

Dapamudang, Faris U. K., Wulandari, Dewi Ariyani, \& Lesmana, Tedy Candra. (2021). Implementasi Bantuan Operasional Kesehatan Puskesmas Wairasa untuk Pencegahan Stunting. JURNAL KESEHATAN MASYARAKAT, 14(1).

Haskas, Yusran. (2020). GAMBARAN STUNTING DI INDONESIA: LITERATUR REVIEW. Jurnal Ilmiah Kesehatan Diagnosis, 15(2), 154-157.

Indrastuty, Dini, \& Pujiyanto, Pujiyanto. (2019). Determinan Sosial Ekonomi Rumah Tangga dari Balita Stunting di Indonesia: Analisis Data Indonesia Family Life Survey (IFLS) 2014. Jurnal Ekonomi Kesehatan Indonesia, 3(2).

Norsanti, Norsanti. (2021). EFEKTIVITAS PROGRAM PERCEPATAN PENURUNAN STUNTING DI KECAMATAN BATUMANDI KABUPATEN BALANGAN (Studi Kasus Pada Desa Mampari dan Desa Banua Hanyar). Jurnal Administrasi Publik Dan Pembangunan, 3(1), 10-21.

Prihatini, Dewi, \& Subanda, I. Nyoman. (2020). Implementasi Kebijakan Alokasi Dana Desa Dalam Upaya Pencegahan Stunting Terintegrasi. Jurnal Ilmiah MEA (Manajemen, Ekonomi, \& Akuntansi), 4(2), 46-59.

Rosha, Bunga Ch, Sari, Kencana, SP, Indri Yunita, Amaliah, Nurilah, \& Utami, N. H. (2016). Peran intervensi gizi spesifik dan sensitif dalam perbaikan masalah gizi balita di Kota Bogor. Buletin Penelitian Kesehatan, 44(2), 127-138.

Sugianto, Made Agus. (2020). The ANALISIS PEMBIAYAAN PENCEGAHAN STUNTING DI KABUPATEN BADUNG DENGAN PENDEKATAN DISTRICT HEALTH ACCOUNT. Jurnal Kesehatan Medika Udayana, 6(01), $52-65$.

Syafrina, Merri, Masrul, Masrul, \& Firdawati, Firdawati. (2019). Analisis komitmen pemerintah Kabupaten Padang Pariaman dalam mengatasi masalah stunting berdasarkan nutrition commitment index 2018. Jurnal Kesehatan Andalas, 8(2), 233-244.

Direktorat Jenderal Bina Pembangunan Daerah Kementerian Dalam Negeri. Arah Kebijakan Nasional Dan Peran Pemerintah Dalam Pencegahan Dan Penanggulan Stunting. 2021. Bekasi.

Peraturan Presiden Nomor 72 Tahun 2021 Tentang Percepatan Penurunan Stunting. 


\section{Copyright holder:}

Rifa'at Hanifa Muslimah, Handar Subhandi Bakhtiar (2021)

First publication right:

KESANS : International Journal Health and Science 